Syntax Literate: Jurnal Ilmiah Indonesia p-ISSN: 2541-0849

e-ISSN: 2548-1398

Vol. 5, No. 8, Agustus 2020

\title{
PERLINDUNGAN HUKUM DALAM MALPRAKTIK UNTUK PELAYANAN KESEHATAN GIGI
}

\section{Endang Sutrisno, Inge Hartini dan Erika}

Pascasarjana Universitas Swadaya Gunungjati (UGJ) Cirebon, Indonesia

Email: endangsutrisno94@gmail.com, raisarei091293@gmail.com dan maryuliyanna@gmail.com

\section{Abstract}

Malpractice can be defined as the negligence or failure of a doctor to use the skill level and knowledge commonly used in treating patients. Orthodontic medical procedures must be carried out with great care so that medical personnel is following their competence and authority. Various possibilities may occur if fixed orthodontic treatment is performed by someone with unsuitable competence including dentists. The findings of the study, in general, dentists already know the rules for limiting authority in performing dental care, especially in the field of fixed orthodontics, but there are still some who violate these rules. Without the competence and authority of a dentist and no referral to a more competent orthodontist specialist, the dentist may be subject to disciplinary and criminal liability under article 69 paragraph (3) of Law Number 24 of 2004 concerning Medical Practice. It takes supervision and guidance by stakeholders, but this is not running optimally.

Keywords: Malpractice; Dentist; Orthodontics

\begin{abstract}
Abstrak
Malpraktik dapat diartikan sebagai sebuah kelalaian atau kegagalan seorang dokter untuk mempergunakan tingkat keterampilan dan ilmu pengetahuannya yang lazim dipergunakan dalam mengobati pasien. Tindakan medis ortodonti harus dikerjakan dengan sangat hati-hati sehingga oleh tenaga medis sesuai dengan kompetensi dan kewenangannya. Berbagai kemungkinan dapat terjadi jika perawatan ortodontik cekat dilakukan oleh seseorang dengan kompetensi yang tidak sesuai termasuk dokter gigi. Temuan penelitian secara umum dokter gigi sudah mengetahui aturan batasan kewenangan dalam melakukan perawatan gigi terutama dibidang ortodonti cekat, namun tetap ada yang melanggar aturan tersebut. Dengan tanpa adanya kompetensi dan kewenangan yang dimiliki dokter gigi serta tidak dilakukan rujukan kepada dokter gigi spesialis ortodonti yang lebih berkompetensi maka dokter gigi tersebut dapat dikenakan sanksi disiplin dan pertanggungjawaban secara pidana berdasarkan pasal 69 ayat (3) Undang- Undang Nomor 24 Tahun 2004 tentang Praktik Kedokteran. Dibutuhkan pengawasan dan pembinaan oleh para pemangku kepentingan, tetpai hal tersebut tidak berjalan optimal.
\end{abstract}

Kata kunci: Malpraktik; Dokter Gigi; Ortodonti. 


\section{Pendahuluan}

Malpraktik adalah sebagai sebuah kelalaian atau kegagalan seorang dokter untuk mempergunakan tingkat keterampilan dan ilmu pengetahuannya yang lazim dipergunakan dalam mengobati pasien (Hanafiah \& Amir, 2019). Keberhasilan upaya kesehatan tergantung pada ketersediaan sumber daya kesehatan itu sendiri seperti tenaga kesehatan, sarana prasarana, serta adminitrasi dengan jumlah dan mutu yang memadai (Sri, 2006). Apabila terjadi malpraktik maka penyelesaian dapat dilakukan secara litigasi dan non litigasi (Arthani \& Citra, 2013). Berdasarkan norma hukum kesehatan bahwa tingkat kesehatan yang optimal harus dilakukan dengan menggunakan pendekatan terintegrasi, komprehensif serta holistik sehingga pembangunan kesehatan untuk seluruh masyarakat dapat tercapai dengan maksimal.

Kesehatan rongga mulut merupakan standar kesehatan gigi serta jaringan lunak sekitar rongga mulut. Kesehatan gigi dan mulut sangat penting untuk keberlangsungan hidup manusia baik dilihat dari segi fungsi maupun estetika (Isfandyarie, 2005). Salah satu dari masalah kesehatan gigi dan mulut adalah maloklusi. Maloklusi yaitu oklusi yang menyimpang dari normal dan merupakan salah satu masalah gigi ketiga paling umum terjadi di antara masalah kesehatan gigi umum lainnya di dunia (Karki, Parajuli, Kunwar, Namgyal, \& Wangdu, 2014). Untuk mengatasi maloklusi dapat terjadi dikarenakan beberapa faktor dan membutuhkan perawatan khusus menggunakan alat-alat ortodonti seperti kawat gigi (Ardyan, 2010). Ortodonti cekat (fixed appliances) adalah salah satu alat ortodonti yang digunakan di kedokteran gigi yang mempunyai fungsi untuk merapikan gigi yang tidak beraturan biasanya melibatkan penggunaan bracket yang dipasang secara permanen pada gigi (Hansu, Anindita, \& Mariati, 2013).

Para dokter gigi umum (general practicioner), spesialis ortodonti (ortodontis) dan spesialis kedokteran gigi anak yang menerapkan ilmu ortodonsia dalam menjalankan prakteknya hendaknya menyadari apa yang menjadi kewenangan masing-masing dalam melakukan perawatan pada pasien agar terhindar dari tuntutan pasien jika dikemudian hari terlibat dalam masalah hukum berkaitan dengan perawatan yang dilakukan (Ardhana, 2013).

Dasar-dasar hukum yang memberikan perlindungan hukum terhadap dokter dalam menjalankan profesi kedokteran apabila terjadi dugaan malpraktek terdapat dalam Pasal 50 Undang-Undang Nomor 29 Tahun 2004 tentang Praktik Kedokteran (UU RI, 2004), pasal 27 ayat (1) dan pasal 29 Undang-Undang Nomor 36 Tahun 2009 tentang Kesehatan (UU RI, 2009). Perlindungan hukum tersebut tidak seperti konsep perlindungan ilmu exact yang selalu dapat terukur (Rompis, 2017).

Berdasarkan latar belakang di atas, pertanyaannya adalah bagaimanakah tanggungjawab dokter gigi yang melakukan pelayanan kesehatan gigi tidak sesuai dengan kompetensinya. 


\section{Metode Penelitian}

Pada penelitian ini paradigma yang dipakai adalah paradigma Critical Legal Studies. Critical Legal Studies (CLS). Jenis penelitian yang digunakan dalam penelitian ini adalah kualitatif. Pendekatan penelitian ini menggunakan social-legal, dengan melihat aspek hukum dalam perspektif gejala sosial atau human action sehingga mencoba menggali hal-hal yang berada dibelakang teks, dalam bentuk produk hukum tertulis sehingga dapat diperoleh pemahaman dan pemaknaan terhadap ketentuan hukum tersebut, dalam ranah keberlakuannya. Penelitian ini menggunakan instrumen yang digunakan yaitu peneliti sebagai instrumen utama.

\section{Hasil dan Pembahasan}

Hukum adalah kristalisasi nilai-nilai yang terdapat di masyarakat (Sutrisno \& Rahayu, 2017). Dalam pemaknaan secara mendalam berkenaan dengan adanya tanggung jawab dalam dimensi norma hukum dipahami dalam koridor ada tindakan berupa tindakan implementatif terhadap sesuatu hal atau perilaku berdasarkan kriteria yag telah ditentukan serta tidak bertentangan dengan norma, tatanan nilai, kaidah yang telah diberlakukan secara umum. Temuan riset membuktikan bahwa dokter gigi pada dasarnya sudah mengetahui aturan batasan kewenangan dalam melakukan perawatan gigi terutama dibidang ortodonti, namun tetap melanggar batasan tersebut. Dalam kajian hukum hal ini tentu akan melanggar norma hukum yang telah dirumuskan bersama khususnya dalam Undang-Undang Tenaga Kesehatan. Regulasi tersebut, telah mengatur secara tegas bahwa profesi yang diemban dibidang kesehatan pada saat melakukan tindakan pelayanan kesehatan harus mengacu kepada kewenangan yang diberikan dengan mendasarkan diri kepada standar kompetensi yang dimilikinya. Hal ini sesuai pula dengan tataran regulasi teknis dalam bentuk produk hukum tertulis Peraturan Menteri Kesehatan.

Dokter gigi dapat melakukan perawatan ortodonti hanya dalam kasus yang sederhana, dengan berdasarkan Peraturan Konsil Kedokteran Indonesia dimaksudkan untuk menjamin rasa kepastian hukum para pihak, yang terlibat dalam pelayanan kesehatan. Jaminan kepastian hukum ini penting mengingat proses bekerjanya hukum, termasuk di bidang kesehatan sangat dipengaruhi oleh berbagai macam faktor lingkungan sekitar tempat norma hukum tersebut berproses dan bekerja.

Perawatan ortodonti cekat full braces sebaiknya dirujuk kepada dokter gigi spesialis ortodonti dimana dokter gigi tersebut lebih berkompeten dalam hal perawatan ortodonti terutama pada kasus yang tergolong kompleks. Dengan tanpa adanya kompetensi dan kewenangan yang dimiliki dokter gigi maka akan sangat mudah untuk menimbulkan kesalahan ketika melakukan perawatan sehingga dapat merugikan secara tidak langsung baik materil maupun inmateril. Hal tersebut menandakan bahwa telah terjadi salah satu pelanggaran disiplin yang yang dilakukan oleh dokter dan dokter gigi sebab melakukan tindakan medis tidak sesuai dengan 
kompetensinya dan tidak melakukan tindakan dengan memberikan solusi terbaik untuk pasien.

Dalam hal ini terdapat sanksi jika melakukan pelanggaran tersebut, hal ini diterangkan pada pasal 4 Perkonsil Kedokteran Indonesia Nomor 4 Tahun 2011 tentang Disiplin profesional dokter dan dokter gigi yang melanggar ketentuan dibebankan dengan kewajiban penerapan sanksi dalam bentuk disiplin. Bentuk sanksi disiplin ini diatur dalam kaidah hukum tertulis mengatur masalah praktik kedokteran bentuk-bentuk sanksi disiplin meliputi hal-hal yaitu diberikannya peringatan secara tertulis, atau rekomendasi pencabutan surat tanda registrasi / surat izin praktik, serta kewajiban mengikuti pendidikan atau pelatihan di institusi pendidikan kedokteran atau kedokteran gigi. Selain merupakan salah satu pelanggaran disiplin dokter, dan dokter gigi tersebut dapat dikenakan pertanggungjawaban secara pidana dengan mengacu kepada kaidah norma praktik kedokteran. Hukum telah mengaturnya secara jelas dan tegas menyangkut hal-hal yang berkenaan dengan tindakan dokter atau dokter gigi dalam melakukan pelayanan kesehatan, hal ini harus dapat dipahami dalam rangka upaya-upaya pencapaian tujuan hukum yaitu keadilan para pihak, kepastian hukum serta kemanfaatan hukum.

Untuk mencegah terjadinya malpraktek atau tidak melaksanakan standar profesi, maka aparat penegak hukum dalam hal ini pihak kepolisian, Jaksa dalam menangani setiap pengaduan yang datangnya dari pasien, keluarga pasien, ataupun kuasa dari pasien, maka sebelum diajukan ke muka sidang pengadilan ia sudah dapat menilai bahwa perkara yang diajukan adalah merupakan kesalahan yang didasari atas pelanggaran etik kedokteran dan aparat penegak hukum tersebut wajib memberitahukan kepada si pengadu bahwa perkara ini akan diselesaikan oleh Ikatan Dokter Indonesia atau Majelis Kehormatan Disiplin Kedokteran Indonesia (MKDKI) sebagai organisasi yang berwenang menanganinya apabila bukan pelanggaran pidana. Sedangkan atas pelanggaran hukum pidana diselesaikan di pengadilan dengan bukti fisik (Nurdin, 2015).

Pemangku Kebijakan (Stakeholder) dalam penanganan malpraktik untuk pelayanan kesehatan gigi, diantaranya Pemerintah Daerah setempat melalui Dinas Kesehatan dan Organisasi Profesi. Berdasarkan proses bekerjanya hukum dalam masyarakat, dipengaruhi oleh environmental law lembaga pembuat aturan adalah pemerintah, dinas kesehatan, dan organisasi profesi. Pemangku kepentingan yaitu Dinas Kesehatan harus melakukan upaya-upaya menerapkan fungsi pengawasan dan pembinaan dokter dan dokter gigi dilakukan oleh Pemerintah Daerah yaitu Dinas Kesehatan. Terdapat dua bentuk pengawasaan yang dilakukan yaitu pengawasan langsung dan tidak langsung.

Dinas Kesehatan memiliki tugas untuk melakukan pengawasan tersebut, sebuah proses kebijakan tahap awal perumusan kebijakan, selanjutnya implementasi kebijakan, tahapan berikut monitoring serta tahapan evaluasi harus dilakukan secara berkesinambungan dalam konteks membangun proses pemberian pelayanan kesehatan dengan tetap menjunjung tinggi mengutamakan keselamatan dokter dan pasien. 


\section{Kesimpulan}

Secara umum dokter gigi sudah mengetahui aturan batasan kewenangan dalam melakukan perawatan gigi terutama dibidang ortodonti, namun tetap melanggar aturan tersebut. Dengan tanpa adanya kompetensi dan kewenangan yang dimiliki dokter gigi serta tidak dilakukan rujukan kepada dokter gigi spesialis ortodonti yang lebih berkompetensi, dokter gigi tersebut dapat dikenakan sanksi disiplin dan dapat dikenai pertanggungjawaban secara pidana. Pemangku kepentingan harus melakukan pembinaan dan pengawasan secara berkesinambungan, hal ini dimaksudkan untuk meminimalisir kemungkinan-kemungkinan oleh sebab pelayanan kesehatan yang diberikannya, misalnya terjadinya malpraktek. 


\section{BIBLIOGRAFI}

Ardhana, Wayan. (2013). Identifikasi Perawatan Ortodontik Spesialistik dan Umum. Majalah Kedokteran Gigi Indonesia, 20(1), 1-8.

Ardyan, Gilang Ramadhan. (2010). Serba Sebi Kesehatam Gigi dan Mulut. Jakarta: Bukuneâ.

Arthani, Ni Luh Gede Yogi, \& Citra, Made Emy Andayani. (2013). Perlindungan hukum bagi pasien selaku konsumen jasa pelayanan kesehatan yang mengalami malpraktek. Jurnal Advokasi, 3(2), 206-214.

Hanafiah, Muhammad Jusuf, \& Amir, Amri. (2019). Etika Kedokteran \& Hukum Kesehatan. EGC.

Hansu, Christy, Anindita, P. S., \& Mariati, Ni Wayan. (2013). Kebutuhan perawatan ortodonsi berdasarkan index of orthodontic treatment need di SMP Katolik Theodorus Kotamobagu. E-GiGi, 1(2).

Indonesia, Republik. (2004). Undang-Undang Nomor 29 Tahun 2004 tentang Praktik Kedokteran. Jakarta: Republik Indonesia.

Indonesia, Republik. (2009). Undang-undang Republik Indonesia nomor 36 tahun 2009 tentang Kesehatan. Jakarta Republik Indones.

Isfandyarie, Anny. (2005). Malpraktek dan resiko medik dalam kajian hukum pidana. Prestasi Pustaka Publisher.

Karki, Saujanya, Parajuli, Umesh, Kunwar, Nischal, Namgyal, Kunsang, \& Wangdu, Khamsum. (2014). Distribution of malocclusion and occlusal traits among Tibetan adolescents residing in Nepal. Orthodontic Journal of Nepal, 4(2), 28-31.

Nurdin, M. (2015). Perlindungan Hukum Terhadap Pasien Atas Korban Malpraktek Kedokteran. Jurnal Hukum Samudra Keadilan, 10(1), 92-109.

Rompis, Michelle Gabriele Monica. (2017). perlindungan hukum terhadap dokter Yang diduga melakukan medical malpraktik. Lex Crimen, 6(4).

Sri, Praptianingsih. (2006). Kedudukan Hukum Perawat dalam Upaya Pelayanan Kesehatan di Rumah Sakit. Jakarta: Raja Grafindo Persada.

Sutrisno, Endang, \& Rahayu, Riris Eka Sri. (2017). Budaya Hukum Dokter Gigi dalam Pelimpahan Wewenang dan Konsekuensi Hukumnya. Kanun Jurnal Ilmu Hukum, 19(3), 399-417. 